\title{
EFFECTIVENESS BETWEEN MANGO HONEY AND KESAMBI HONEY AS ANTIBACTERIAL AGAINST STREPTOCOCCUS PYOGENES
}

\author{
Salvador BHWD Borromeu ${ }^{1)}$, Endang Isbandiati' ${ }^{2)}$, Adi Pramono ${ }^{3)}$
}

\begin{abstract}
Introduction: Infectious disease is one of the biggest health problems in developing countries, including Indonesia. The development of the discovery of antibiotics was not balanced with the development of resistance that occurred after that Group A streptococcus $\beta$ hemolytic causes various events of a severe degree of infection. Now many people use natural ingredients as an alternative to antibiotics, one of which is honey.

Aim: Knowing the benefits of mango honey and kesambi honey as an antibacterial against Streptococcus pyogenes and knowing the difference in the effectiveness and potency to inhibit growth and kill Streptococcus pyogenes between the two honey.

Method: Using the macro dilution method in determining the value of MIC and the streaking method to determine the value of MBC.

Results: MIC mango honey at $15.625 \mu \mathrm{L}$, MIC kesambi honey at $15.625 \mu \mathrm{L}, \mathrm{MBC}$ mango honey at $15.625 \mu \mathrm{L}$, and MBC kesambi honey at $31.25 \mu \mathrm{L}$.

Conclusion: There is a difference of $\mathrm{MBC}$ between mango honey and kesambi honey against Streptococcus pyogenes where mango honey at $15.625 \mu \mathrm{L}$ and kesambi honey at $31.25 \mu \mathrm{L}$, there is no difference in MIC between mango honey and kesambi honey, and the effectiveness and potency of mango honey as an antibacterial against Sp higher than kesambi honey which was observed through differences in the value of MBC.
\end{abstract}

Keywords: MIC, MBC, mango honey, kesambi honey, Streptococcus pyogenes.

1) Student of Faculty of Medicine, Widya Mandala Catholic University of Surabaya, Jl. Kalisari Selatan No. 1 Surabaya. Email : widodoborromeu@gmail.com

2) Pharmacology and Therapy Department, Faculty of Medicine, Widya Mandala Catholic University of Surabaya, Jl. Kalisari Selatan No. 1 Surabaya

3) Clinical Pathology Department, Faculty of Medicine, Widya Mandala Catholic University of Surabaya, Jl. Kalisari Selatan No. 1 Surabaya 


\section{INTRODUCTION}

Infectious disease is one of the biggest health problems in developing countries, including Indonesia. The 2007 Household Health Survey provides an overview of some of the highest causes of death, including $28.1 \%$ caused by infectious diseases, $18.9 \%$ caused by vascular disease, and $15.7 \%$ caused by respiratory diseases ${ }^{1}$.

The discovery of penicillin as an antibiotic by Sir Alexander Fleming in 1928 was significant to fight bacterial infections. Since then, antibiotics have changed modern medicine and saved many lives. In the 1940s, antibiotics were first prescribed to treat serious infections ${ }^{2}$. The development of antibiotics did not account for development of resistance that occurs in microorganisms that cause infectious diseases after that. resistance occurs due to excessive use of antibiotics and inappropriate prescribing. Some public health organizations declare the emergence and development of resistance events as "crises" or "nightmare scenarios" that can have "catastrophic consequences." The Centers for Disease Control and Prevention (CDC) states that in 2013 humanity is in the "post-antibiotic era." The World Health Organization (WHO) in 2014 stated that the incidence of antibiotic resistance crises became increasingly dire ${ }^{3}$.
Streptococcus pyogenes is a member of the Streptococcus group A bacteria, which is $\beta$ hemolyticus. This bacterium causes various events of severe infection. Infection that is often caused in the form of streptococcal pharyngitis or commonly called strep throat, impetigo, middle ear infection, mastoiditis, and also other infections that spread hematogenously such as glomerulonephritis and acute rheumatic fever ${ }^{4}$. All Streptococcus groups are sensitive to the penicillin group antibiotics, especially penicillin G. Penicillin is useful in more than $90 \%$ of cases and is generally used as the drug of choice. Tetracycline antibiotics and sulfonamide groups are generally not recommended because Streptococcus rapidly develops resistance to these drugs 5 . There is also a mention that Streptococcus pyogenes has been resistant to erythromycin and other macrolide groups ${ }^{6}$.

If resistance continues to occur and increases, it is feared that common treatment of infectious diseases will fail so that morbidity and mortality rates will rise. Today many people use natural ingredients as an alternative to antibiotics, one of which is honey. Honey is a natural substance produced by honey bees, produced from the nectar of flowers or plant secretions collected by honey bees and then converted and stored in beehives for maturation ${ }^{7}$. Honey has many uses for 
health benefits, beauty purposes and can be used as food sweeteners, food seasonings, and beverage mixes. Honey can also be used to treat fevers, prevent thrush, treat coughs, heal wounds, and maintain immunity ${ }^{8}$. Honey can suppress the growth of certain bacteria through several mechanisms, including high sugar levels that can inhibit bacteria from living and developing. High acidity levels can inhibit the growth and survival rate of bacteria so that bacteria will die. Honey has a radical compound hydrogen peroxide (H2O2) that can kill microorganisms that cause disease. There are antibacterial organic compounds (for example, flavonoids), which are currently often used as a basis for modern antibacterial drugs ${ }^{9}$. Each type of honey has different chemical composition depending on the source of the nectar. This difference is thought to produce differences in antibacterial activity between honey ${ }^{10}$. For the reasons stated above, a study was carried out to determine the antibacterial activity and study the difference in effectiveness and antibacterial potential between mango honey and kesambi honey against Streptococcus pyogenes.

\section{METHOD}

This research was an experimental study using an actual experiment with a post-test-only control group design, divided into two groups: the treatment group and the control group. This research was conducted at the Pharmacy Faculty Research Laboratory at Widya Mandala Catholic University Surabaya, and the Clinical Microbiology Laboratory at the Center for Health Laboratory of Surabaya. The population of this research was Streptococcus pyogenes. Samples taken were Streptococcus pyogenes ATCC 19615 obtained from the Clinical Microbiology Laboratory at the Center for Health Laboratory of Surabaya. The levels of mango honey and kesambi honey used were $15.625 \mu \mathrm{L}, 31.25 \mu \mathrm{L}, 62.5 \mu \mathrm{L}, 125$ $\mu \mathrm{L}$, and $250 \mu \mathrm{L}$.

\section{Honey Setup}

The two honey samples used, namely mango honey and kesambi honey, were purchased from honey producers who took mango honey from beehives in the mango tree and kesambi honey from beehives in the kesambi tree in Atambua City area, Belu Regency, NTT. Honey was taken from beehives in the forest by honey farmers and then processed to get pure honey. Honey was tested for $\mathrm{pH} /$ acidity and flavonoid content as a differentiator between mango honey and kesambi honey in the Pharmacy Faculty Research Laboratory at Widya Mandala Catholic University Surabaya. Furthermore, both sterility of honey was tested at the Clinical Microbiology Laboratory at the Center for 
Health Laboratory of Surabaya to determine whether there was bacterial contamination. After that, the two honey samples were used in the KHM and KBM testing procedures.

\section{Making bacterial suspensions}

bacterial culture that has been grown was taken with a sterile loop and then suspended in a tube containing $0.9 \% \mathrm{NaCl}$ solution to obtain the same turbidity suspension bacterium with standard turbidity of $0.5 \mathrm{Mc}$ Farland on Mc Farland densitometer which is equivalent to $1.5 \mathrm{x}$ $108 \mathrm{CFU} / \mathrm{ml}^{11}$.

\section{Antibacterial Test}

Testing for antibacterial activity was carried out using the macro dilution method. This study was divided into control groups and treatment groups.

$\mathrm{K}_{\mathrm{x} 1-5 ; \mathrm{y} 1-5}=$ Negative control groups

$\mathrm{K}_{\mathrm{x} 1-5}=$ Negative control of mango honey

$\mathrm{K}_{\mathrm{x} 1}=$ Mango honey 15,625 microliter

$(\mu \mathrm{l})+$ Mueller Hinton Broth (MHB)

$\mathrm{K}_{\mathrm{x} 2}=$ Mango honey 31,25 $\mu 1+\mathrm{MHB}$

$\mathrm{K}_{\mathrm{x} 3}=$ Mango honey $62,5 \mu 1+\mathrm{MHB}$

$\mathrm{K}_{\mathrm{x} 4}=$ Mango honey $125 \mu \mathrm{l}+\mathrm{MHB}$

$\mathrm{K}_{\mathrm{x} 5}=$ Mango honey $250 \mu \mathrm{l}+\mathrm{MHB}$

$\mathrm{K}_{\mathrm{y} 1-5}=$ Negative control of kesambi honey

$\mathrm{K}_{\mathrm{y} 1}=$ Kesambi honey $15,625 \mu 1+$

MHB

$\mathrm{K}_{\mathrm{y} 2}=$ Kesambi honey $31,25 \mu \mathrm{l}+$

MHB

$\mathrm{K}_{\mathrm{y} 3}=$ Kesambi honey $62,5 \mu 1+$ MHB

$\mathrm{K}_{\mathrm{y} 4}=$ Kesambi honey $125 \mu \mathrm{l}+\mathrm{MHB}$
$\mathrm{K}_{\mathrm{y} 5}=$ Kesambi honey $250 \mu \mathrm{l}+\mathrm{MHB}$

$\mathrm{K}_{\mathrm{z}}=$ Media control group

$\mathrm{K}_{\mathrm{z}}=$ Bacterial suspension

Streptococcus pyogenes $+\mathrm{MHB}$

$\mathrm{K}_{\mathrm{a}}=$ Positive control group

$\mathrm{K}_{\mathrm{a}}=$ Bacterial suspension

Streptococcus pyogenes $+\mathrm{MHB}+$

Penicillin G

$\mathrm{P}_{\mathrm{x} 1-5 ; \mathrm{y} 1-5}=$ Treatment groups

$\mathrm{P}_{\mathrm{x} 1-5}=$ Mango honey treatment

$\mathrm{P}_{\mathrm{x} 1}=$ Mango honey $15,625 \mu \mathrm{l}+\mathrm{MHB}$

+ Bacterial suspension Streptococcus

pyogenes

$\mathrm{P}_{\mathrm{x} 2}=$ Mango honey $31,25 \mu 1+\mathrm{MHB}+$

Bacterial suspension Streptococcus

pyogenes

$\mathrm{P}_{\mathrm{x} 3}=$ Mango honey $62,5 \mu \mathrm{l}+\mathrm{MHB}+$

Bacterial suspension $\mathrm{Sp}$

$\mathrm{P}_{\mathrm{x} 4}=$ Mango honey $125 \mu \mathrm{l}+\mathrm{MHB}+$

Bacterial suspension $\mathrm{Sp}$

$\mathrm{P}_{\mathrm{x} 5}=$ Mango honey $250 \mu 1+\mathrm{MHB}+$

Bacterial suspension Streptococcus

pyogenes

$\mathrm{P}_{\mathrm{y} 1-5}=$ Kesambi honey treatment

$\mathrm{P}_{\mathrm{y} 1}=$ Kesambi honey 15,625 $\mu 1+$

MHB + Bacterial suspension

Streptococcus pyogenes

$\mathrm{P}_{\mathrm{y} 2}=$ Kesambi honey 31,25 $\mu 1+$ MHB

+ Bacterial suspension Streptococcus pyogenes

$\mathrm{P}_{\mathrm{y} 3}=$ Kesambi honey 62,5 $\mu 1+$ MHB

+ Bacterial suspension Streptococcus pyogenes 
$\mathrm{P}_{\mathrm{y} 4}=$ Kesambi honey $125 \mu \mathrm{l}+\mathrm{MHB}+$ Bacterial suspension Streptococcus pyogenes

$\mathrm{P}_{\mathrm{y} 5}=$ Kesambi honey $250 \mu \mathrm{l}+\mathrm{MHB}+$

Bacterial suspension Streptococcus pyogenes

$\mathrm{H}=\mathrm{KHM}$ dan $\mathrm{KBM}$

Determination of MIC of mango honey and kesambi honey against bacteria Streptococcus pyogenes was through visual means of observing the lowest levels of honey in the treatment tube with the same clarity as a negative control tube the same levels and types of honey after incubated at $37^{\circ} \mathrm{C}$ for 24 hours. Visual observations were made in a room exposed to sunlight, carried out at the same time by three different people.

Determination KBM of mango honey and kesambi honey against Streptococcus pyogenes bacteria was done by calculating the number of colonies from the results of honey streaking with the lowest levels of the treatment tube determined as MIC to the highest concentration of honey compared with negative controls with the same levels and types of honey. No bacterial growth was obtained in the form of the number of colonies after incubation at $37^{\circ} \mathrm{C}$ for 24 hours on Blood Agar.

\section{RESULTS}

Visual Observation Results of KHM Honey Mango Test Tube
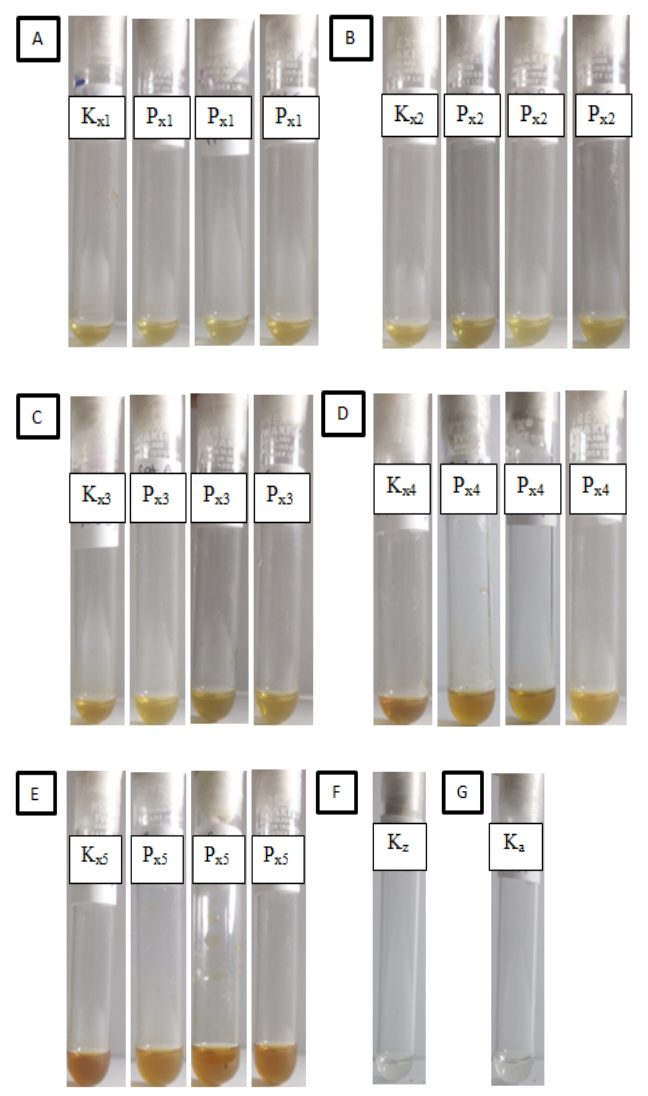

Figure 1. Tubes containing treatment and control of MIC test of mango honey.

From the observations, it was found that 15.625 $\mu \mathrm{L}$ (Px1), 31.25 $\mu \mathrm{L}$ (Px2), $62.5 \mu \mathrm{L}$ (Px3), $125 \mu \mathrm{L}$ (Px4), and $250 \mu \mathrm{L}(\mathrm{Px} 5)$ could inhibit the growth of Streptococcus pyogenes. Then the MIC value of mango honey against Streptococcus pyogenes is 15,625 $\mu \mathrm{L}(\mathrm{Px} 1)$ because the levels of mango honey are $15,625 \mu \mathrm{L}(\mathrm{Px} 1)$ smaller than the levels of mango honey $31.25 \mu \mathrm{L}$ (Px2), 62.5 $\mu \mathrm{L}$ (Px3), $125 \mu \mathrm{L}$ (Px4)), and $250 \mu \mathrm{L}(\mathrm{Px} 5)$. 


\section{Visual Observation Results of Kesambi}

Honey KHM Test Tubes

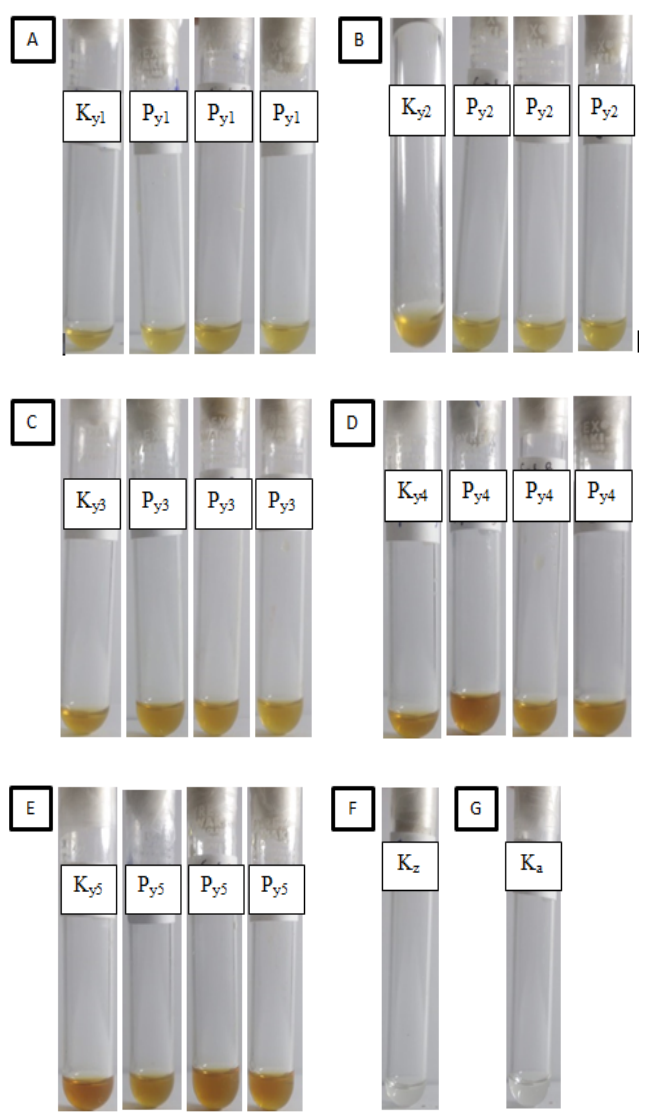

Figure 2. Tubes containing treatment and control of MIC test of kesambi honey.

From the observation, it was found that honey porch 15.625 $\mu \mathrm{L}$ (Py1), 31.25 $\mu \mathrm{L}$ (Py2), $62.5 \mu \mathrm{L}$ (Py3), $125 \mu \mathrm{L}$ (Py4), and $250 \mu \mathrm{L}$ (Py5) could inhibit the growth of Streptococcus pyogenes. Then the KHM value of kesambi honey against Streptococcus pyogenes was 15,625 $\mu \mathrm{L}$ (Py1) because the level of kesambi honey is $15,625 \mu \mathrm{L}$ (Py1) smaller than the level of kesambi honey $31.25 \mu \mathrm{L}$ (Py2), $62.5 \mu \mathrm{L}$ (Py3), $125 \mu \mathrm{L}$ (Py4), and $250 \mu \mathrm{L}$ (Py5).

Streaking Observation Results of Mango Honey on Blood Agar
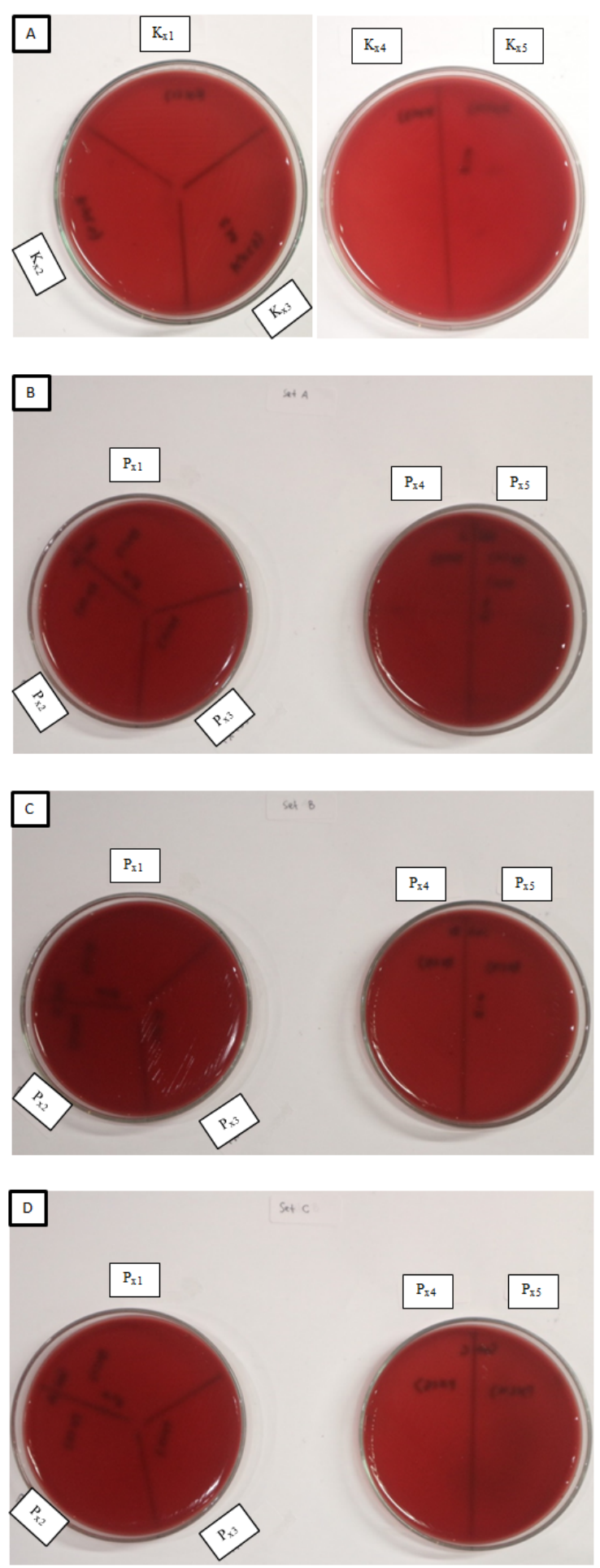

Figure 3. Plates contain treatment and control of MBC test of mango honey.

It can be concluded that carrying mango honey levels of 15,625 $\mu \mathrm{L}$ (Px1), $31.25 \mu \mathrm{L}$ (Px2), $62.5 \mu \mathrm{L}$ (Px3), $125 \mu \mathrm{L}$ (Px4), and $250 \mu \mathrm{L}(\mathrm{Px} 5)$ had the killing power against Streptococcus pyogenes, so the value of KBM mangoes honey against 
Effectiveness Between Mango...

Streptococcus pyogenes was levels of 15,625 $\mu \mathrm{L}$ (Px1) because mango honey levels of 15,625 $\mu \mathrm{L}$ (Px1) was lower than mango honey levels of $31.25 \mu \mathrm{L}$ (Px2), $62.5 \mu \mathrm{L}(\mathrm{Px} 3), 125 \mu \mathrm{L}(\mathrm{Px} 4)$, and $250 \mu \mathrm{L}$ (Px5)

\section{Observation of Streaking Kesambi}

Honey on Blood Agar
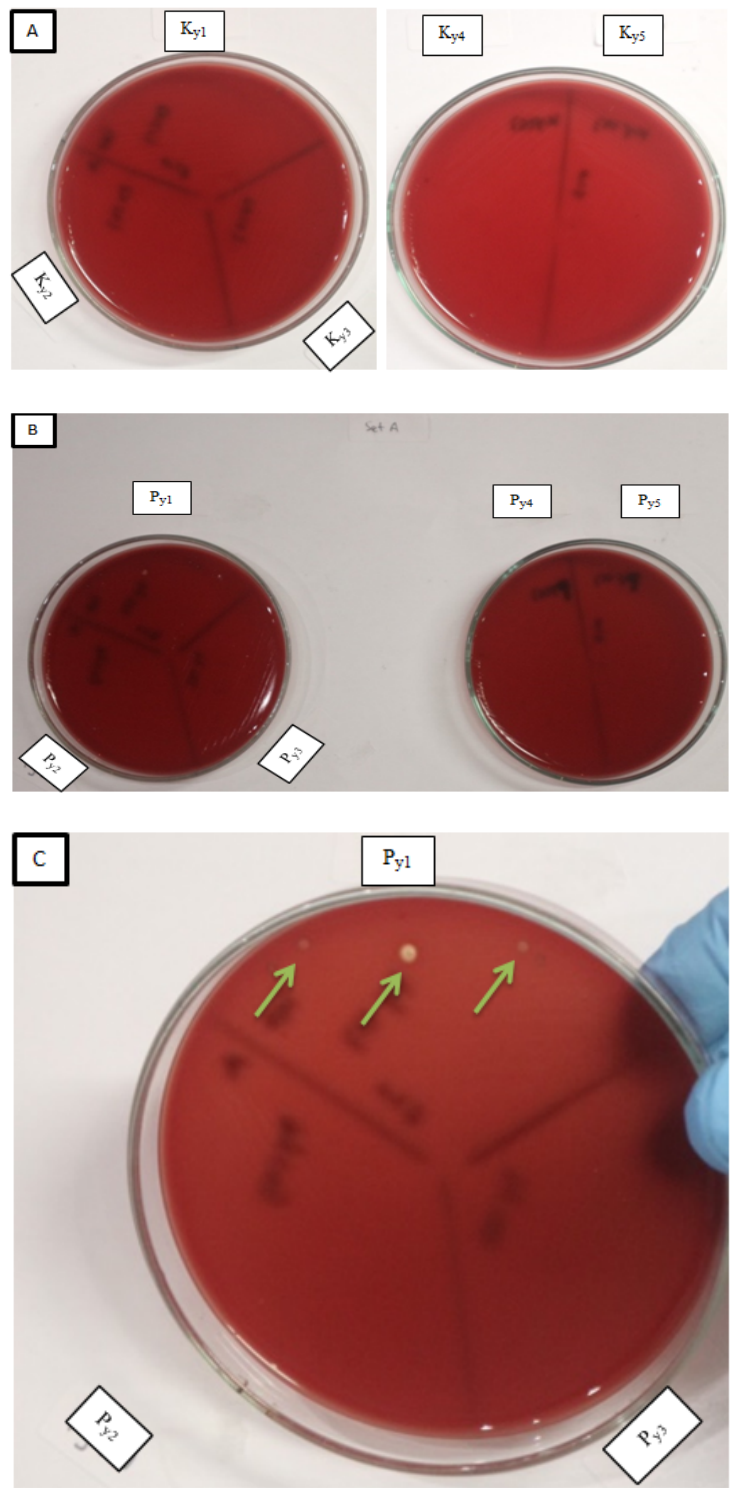

Borromeu SBHWD, Isbandiati E, Pramono A

D
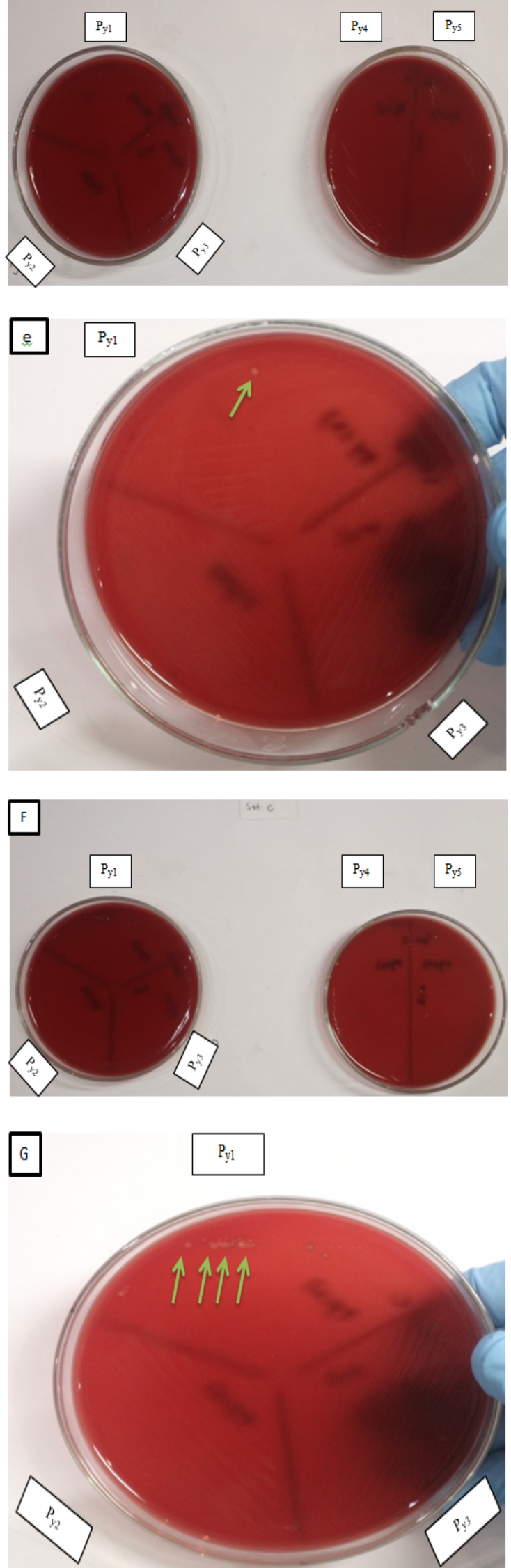

Picture 4. Plates contain treatment and control of MBC test of kesambi honey. 
It can be concluded that carrying honey from levels of $15,625 \mu \mathrm{L}$ (Py1) had no killing power against Streptococcus pyogenes. In comparison, kesambi honey content of $31.25 \mu \mathrm{L}$ (Py2), $62.5 \mu \mathrm{L}$ (Рy3), $125 \mu \mathrm{L}$ (Py4), and $250 \mu \mathrm{L}$ (Py5) had the killing power of Streptococcus pyogenes, so that the minimum kill rate of the kesambi honey against Streptococcus pyogenes was a level of $31.25 \mu \mathrm{L}$ (Py2) because mango honey content of $31.25 \mu \mathrm{L}$ (Py2) was lower than honey kesambi content of $62.5 \mu \mathrm{L}$ (Py3), $125 \mu \mathrm{L}$ (Py4), as well as $250 \mu \mathrm{L}$ (Py5) and the lowest kesambi honey content was $15.625 \mu \mathrm{L}$ (Py1) had no killing power against Streptococcus pyogenes.

\section{DISCUSSION}

The results obtained in this study were the KHM in mango honey was $15,625 \mu \mathrm{L}$, the KHM in kesambi honey was 15,625 $\mu \mathrm{L}$, the $\mathrm{KBM}$ in mango honey was 15,625 $\mu \mathrm{L}$, and the KBM in kesambi honey was $31.25 \mu \mathrm{L}$. It can be said that there were differences in the effectiveness and potential between mango honey and kesambi honey, which is indicated by the differences in the KBM of the two honey. Researchers suspect this difference was caused by various factors, including the content in both kinds of honey.

In general, four factors are supporting the antibacterial ability of honey, namely high levels of sugar can inhibit the development and growth of bacteria; the acidic nature of honey $(\mathrm{pH}$ in the range 34) makes bacteria unable to survive; organic antibacterial compounds such as inhibine from the flavonoid group, glycosides, and polyphenols in honey; and honey contains radical compounds that can kill bacteria and other pathogenic microorganisms, namely hydrogen peroxide $^{12}$.

Total sugar levels are generally affected by water content and acidity ${ }^{13}$. High sugar content will cause honey to become concentrated or thick, making honey has hygroscopic properties. Hygroscopic properties of honey are determined by fructose because fructose is more soluble than glucose ${ }^{14}$. The composition of sugar in honey is influenced by geographical conditions such as climate, environment, soil type, plant vegetation composition, nectar quality, and storage conditions ${ }^{15}$. In general, high levels of honey sugar can inhibit the growth and development of bacteria due to osmotic pressure (water movement from low solute concentrations to high solute concentrations). The intense interaction between sugar molecules and water molecules leaves minimal amounts of water molecules for bacteria. When water drops to a minimum level for growth, bacteria can stay alive for a while. However, if the water drops dramatically, 
the bacteria will lose its ability to live. Very high glucose and fructose content cause honey to be very hypertonic compared to the environment in the bacterial body; this trait will cause bacterial lysis due to severe dehydration due to the osmosis effect ${ }^{16,17}$. In this study, sugar testing was not carried out on mango honey and kesambi honey. It could not be used as an evaluation material for differences in the antibacterial ability between mango honey and kesambi honey.

The $\mathrm{pH}$ value can determine the degree of acidity of the honey, the higher the acidity of honey the lower the $\mathrm{pH}$ of ${ }^{18}$. The $\mathrm{pH}$ value can be different due to differences in mineral and acid content in honey ${ }^{19}$. Several acids can affect the $\mathrm{pH}$ of honey, such as amino acids (0.05 to $0.1 \%)$ and organic acids (average $0.57 \%$, ranging from 0.17 to 1.175$)$. The dominant amino acid in honey is proline, and the dominant organic acid is gluconic. The enzyme glucose oxidase produces gluconic acid20. High water content in honey can cause the fermentation process to occur more quickly, thereby affecting its acidity ${ }^{13}$. Acidity has a significant influence on the growth and survival of bacteria. Each species has an optimum acidity for growth. When the $\mathrm{pH}$ drops to the lowest level for bacterial growth, the bacteria will not only stop growing but also lose the ability to live ${ }^{21}$.
High amounts of acid can denature bacterial cell proteins by disrupting the salt bridge by an ionic charge $\mathrm{e}^{22}$. The acidic $\mathrm{pH}$ of honey will inhibit bacterial metabolism so that it will easily undergo lysis, which can inhibit bacterial growth ${ }^{23}$. Honey with high acidity causes the concentration of hydrogen ion to increase. This can disrupt the membrane proton gradient in bacterial cells $^{16,17}$. In this study, after checking the $\mathrm{pH}$ value, the mango honey had a $\mathrm{pH}$ of 3.33, and kesambi honey had a $\mathrm{pH}$ of 3.00. Following the theory that Streptococcus pyogenes is a bacterium that grows optimally in the $\mathrm{pH}$ range of 7.4-7.65, so that with high acidity, mango honey with a $\mathrm{pH}$ of 3.33 and kesambi honey with a $\mathrm{pH}$ of 3.00 which is lower than the optimum $\mathrm{pH}$ Streptococcus pyogenes $(\mathrm{pH}$ 7.4-7.6) enables mango honey and kesambi honey to inhibit growth and kill Streptococcus pyogenes. this $\mathrm{pH}$ difference may be one of the distinguishing factors in the inhibitory and killing ability between the two honey. according to this theory, kesambi honey with a lower $\mathrm{pH}$ of 3.00 should inhibit growth and kill Streptococcus pyogenes bacteria better than mango honey with a higher $\mathrm{pH}$ of 3.33. The results of the comparison of the MIC and KBM values showed mango honey can inhibit growth and kill Streptococcus pyogenes bacteria better than kesambi honey, therefore this is 
thought to be influenced by other antibacterial honey content.

Honey contains organic compounds that are antibacterial such as inhibine from the flavonoid group, glycosides, and polyphenols. Flavonoids are one of the phytochemical contents most often found in honey. This compound is a reducing compound that can inhibit many oxidation reactions through enzymatic and nonenzymatic processes. The function of flavonoids is as a reservoir of hydroxy radicals and superoxide ${ }^{24}$. The mechanism of action of these organic compounds as antibacterial through poisoning protoplasm, damaging and penetrating cell walls, and depositing microbial cell proteins. Honey is dark in color because it contains more phenolic components than bright honey ${ }^{25}$. Mango honey and kesambi honey used in this study are dark in color, which means they contain many phenolic components. Abundant molecular phenolic compounds can activate essential enzymes in microbial cells, even at deficient concentrations. The phenol compound can break the peptidoglycan bond when it breaks through the cell wall. After breaking through the bacterial cell wall, phenol compounds will cause leakage of cell contents by damaging the hydrophobic bonds of cell membrane components (such as proteins and phospholipids) and dissolving the hydrophobic binding components resulting in an increase in membrane permeability that causes the bacterial cell contents to come out. Damage to the cell membrane causes the activity and biosynthesis of specific enzymes needed in bacterial metabolic reactions to be inhibited ${ }^{26}$. After examining the flavonoid content qualitatively to determine the presence of flavonoids in this study, the results showed that mango honey and kesambi honey contain positive flavonoid compounds, which affect the ability of mango honey and honey kesambi in inhibiting growth and killing bacteria. In this study, a quantitative examination of flavonoid content was not carried out to determine the levels of flavonoids in mango honey and kesambi honey. It could not be used as further consideration to support the difference in MIC and MBC values between the two honey.

Some critical enzymes in honey are the diastase, invertase, glucose oxidase, peroxidase, and lipase ${ }^{27}$. The glucose oxidase enzyme can increase the antibacterial ability by converting glucose in honey to gluconic acid and hydrogen peroxide. Hydrogen peroxide compounds can kill bacteria. These compounds can reactively damage the functional groups of bacterial cell biomolecules. The mechanism of hydrogen peroxide action is to denature proteins and inhibit the synthesis or function of bacterial nucleic 
acids, with damage to the bacterial cell wall and interference with nucleic acid synthesis, causing inhibited bacterial growth $^{28}$. The content of hydrogen peroxide is cytotoxic to bacterial cells. Antimicrobial hydrogen peroxidase process through the ability to oxidize and the formation of hydroxyl free radicals that are more toxic to facilitate bacterial cell damage $^{23}$. The catalase enzyme converts hydrogen peroxide into water and oxygen ${ }^{4}$. The catalase test results give a negative result, meaning that Streptococcus pyogenes used for this research do not have the catalase enzyme to hydrolyze hydrogen peroxide, which is one of the factors supporting the ability of honey as an antibacterial. In this study, there was no testing of hydrogen peroxide compounds both qualitatively and quantitatively so that it could not be used as a benchmark further in determining differences in the effectiveness of the antibacterial ability of the two honey.

The alternate hypothesis in this study was supported by the results obtained that mango honey can inhibit Streptococcus pyogenes as evidenced by the MIC value of mango honey which is $15,625 \mu \mathrm{L}$, kesambi honey can inhibit the growth of Streptococcus pyogenes as evidenced by the KHM value of honey kesambi which is 15,625 $\mu \mathrm{L}$, mango honey can kill Streptococcus pyogenes which is proven through KBM value of mango honey that is $15,625 \mu \mathrm{L}$, kesambi honey can kill $\mathrm{S}$. pyogenes which is proven through $\mathrm{KBM}$ value of kesambi honey which is $31.25 \mu \mathrm{L}$, and there are differences in the effectiveness and potency between mango honey and kesambi honey which is seen through KBM value that is KBM Mango honey at a level of $15,625 \mu \mathrm{L}$ is smaller than KBM honey kesambi at a level of $31,25 \mu \mathrm{L}$ which indicates that mango honey is more effective and potent because with a smaller level it can kill Streptococcus pyogenes.

\section{CONCLUSION}

In this study, the following conclusions are obtained:

1. Mango honey has MIC at levels 15,625 $\mu \mathrm{L}$ and $\mathrm{KBM}$ at levels 15,625 $\mu \mathrm{L}$ against Streptococcus pyogenes.

2. Kesambi honey has a KHM at a level of $15,625 \mu \mathrm{L}$ and a KBM at a level of 31,25 $\mu \mathrm{L}$ against Streptococcus pyogenes.

3. There is a difference in the value of KBM between mango honey and kesambi honey against Streptococcus pyogenes, namely mango honey at a level of $15,625 \mu \mathrm{L}$ and kesambi honey at a level of $31,25 \mu \mathrm{L}$.

4. There is no difference in the MIC value between mango honey and kesambi honey. 
5. The potential of mango honey as an antibacterial agent against Streptococcus pyogenes is higher than that of kesambi honey, which was observed through differences in the values of $\mathrm{KBM}$.

\section{ACKNOWLEDGEMENT}

Faculty of Medicine Widya Mandala Catholic University of Surabaya, Pharmacy of Widya Mandala Catholic University of Surabaya, Clinical Microbiology Laboratory of Center for Health Laboratory of Surabaya.

\section{References}

1. Aniq A, Mutsaqof N, Suryani E, Kom SSM. Sistem Pakar Untuk Mendiagnosis Penyakit Infeksi Menggunakan Forward Chaining. 2015;4(1):43-7.

2. Ventola CL. The Antibiotic Resistance Crisis Part 1: Causes and Threats. 2015;40(4):277-83.

3. Suwarto S. Penyakit Tropik dan Infeksi pada Abad 21: Apakah Masih Relevan ? 2019;77-8.

4. Leboffe MJ, Pierce BE. A Photographic Atlas For The 4th Edition Microbiology Laboratory. Englewood, CO: Morton Pub. Co.; 2011.

5. Bhatia R, Ichhpujani RL. Essentials Of Medical Microbiology. New Delhi: Jaypee Brothers; 2008.
6. Winarno FG. Madu: Teknologi, Khasiat, dan Analisa. Jakarta Timur: Ghalia Indonesia; 1982.

7. Johnson S, Nimisha J. Antibiotic Residues In Honey. Dalam: Center for Science and Environment. New Delhi: Tughlakabad Institutional Area; 2010.

8. Mulu A, Tessema B, Derbie F. In Vitro Assessment Of The Antimicrobial Potential Of Honey On Common Human Pathogens. Ethiopian Journal of Health Development. 2005;18(2).

9. Kamaruddin. Khasiat Madu. Kuala Lumpur: Departement of Biochemistry, Faculty of Medicine, Universitas of Malaya; 2002.

10. Parwata IOA, Ratnayani K, Listya A. Aktivitas Antiradikal Bebas Serta Kadar Beta Karoten Pada Madu Randu (Ceiba pentandra) Dan Madu Kelengkeng (Nephelium longata L.). J Kim 4. 2010;4(1):5462.

11. Tille PM. Bailey's \& Scotts's Diagnostic Microbiology. Fourteenth. St.Louis, Missouri: Elsevier; 2017.

12. Zulhawa DJ. Daya Hambat Madu Sumbawa Terhadap Pertumbuhan Kuman Staphylococcus aureus Isolat Infeksi Luka Operasi RS Islam Amal Sehat Sragen. Fakultas 
Effectiveness Between Mango...

Kedokteran Universitas Sebelas Maret: 2010.

13. Putu N, Savitri T, Hastuti ED, Widodo S, Suedy A. Kualitas Madu Lokal dari Beberapa Wilayah di Kabupaten Temanggung. Bul Anat dan Fisiol. 2017;2(1):58-66.

14. Shugaba A. Analysis of Biochemical Composition of Honey Samples from North-East Nigeria. Biochemistry \& Analytical Biochemistry. 2012;2(3).

15. Minarti S, Jaya F, Merlina PA. Pengaruh Masa Panen Madu Lebah Pada Area Tanaman Kaliandra (Caliandra Calothyrsus) Terhadap Jumlah Produksi, Kadar Air, Viskositas, dan Kadar Gula Madu.

J Ilmu dan Teknol Has Ternak. 2016;11(1):46-51.

16. Andriani M, Utami R, Hariyati LF. Aktivitas Antibakteri Berbagai Jenis Madu Terhadap Bakteri Pembusuk (Pseudomonas fluorescens FNCC 0071 dan Pseudomonas putida FNCC 0070). Biomedika [Internet]. 2012;5(1). Available from: https://eprints.uns.ac.id/13215/1/Pu blikasi_Jurnal_(7).pdf.

17. Samaranayake L. Essential Microbiology for Dentistry. 4th ed. St. Louis: Churchill Livingstone Elsevier; 2012. 58-59 p.
Borromeu SBHWD, Isbandiati E, Pramono A

18. Hikmawati, Noor A., Natzir H. Hikmawati, Mikro Mineral Essensial (Co, Ni dan V) serta Sifat Bio-Fisika Kimia pada Madu Asal Mallawa. Jurusak Kim Fak Mat dan Ilmu Pengetah Alam, Univ Hasanudin. 2013;1-8.

19. Gulfraz M, Iftikhar F, Imran $M$, Zeenat A, Asif S, Shah I. Compositional analysis and antimicrobial activity of various honey types of Pakistan. International Journal of Food Science \& Technology. 2011;46(2):263-7.

20. Honey-Health and Therapeutic Qualities. USA: The National Honey Board; 2003. Available from: Http:// www.jorgensensapiary.com/pdf/co mpedium.pdf.

21. Ray B, Bhunia AK. Fundamental Food Microbiology. Boca Raton: CRC Press; 2014.

22. Ambarwati, Enda F, Utami DF. Pengaruh Pemberian Larutan Ekstrak Jeruk Nipis (Citrus aurantifolio) Terhadap Pembentukan Plak Gigi. Fakultas Kedokteran: 2012. Available from: http://eprints. undip.ac.id/ 37540.
23. Suriawiria
U.
Pengantar
Mikrobiologi Umum. Angkasa Bandung; 2000. 
24. Gunawan R. Uji Fitokimia dan Penentuan Aktivitas Antioksidan Dari Madu Trigona Incisa. 2018;18-21.

25. Eleazu CO, Iroaganachi MA, Eleazu KC, Okoronkwo JO. Determination of the PhysicoChemical Composition, Microbial Quality, and Free Radical Scavenging Activities of Some Commercially Sold Honey Samples in Aba, Nigeria: 'The Effect of Varying Colors. International Journal of Biomedical Research. 2013;4(1):32-41.

26. Zulhawa DJ, Maryani, Dewi NH. Daya Hambat Madu Sumbawa terhadap Pertumbuhan Staphylococcus aureus Isolat Infeksi Luka Operasi. Biofarmasi. 2014;12(1):40-4.
27. Nadhilla NF. The Activity Of Antibacterial Agent Of Honey Against Staphylococcus aureus. JukeKedokteranUnilaAcId. 2014;3:94-101.

28. Molan PC. The Antibacterial Activity of Honey. Bee World. 1992;73(2):59-76. 